\title{
PHYSICAL ACTIVITY IN THE TREATMENT OF DEPRESSION IN COLLEGE STUDENTS
}

\author{
ATIVIDADE FISICA NO TRATAMENTO DA DEPRESSÃO EM ESTUDANTES UNIVERSITÁRIOS \\ LA ACTIVIDAD FÍSICA EN EL TRATAMIENTO DE LA DEPRESIÓN EN ESTUDIANTES UNIVERSITARIOS
}

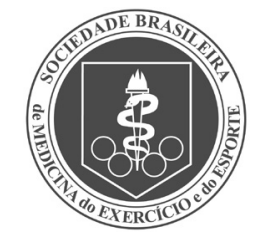

Original Article

ARTIGO ORIGINAL Artículo Original
Xiaowei $\mathrm{He}^{1}$ (DD

(Physical Education Professional)

1. Chongqing Finance and Economics College, Department of Marxist, Chongqing, China.

\section{Correspondence:}

Xiaowei He. Chongqing,

China. 401320.

hexiaowei842021@163.com

\begin{abstract}
Introduction: The mental health of college students is getting more and more attention from society. Physical exercise as a means of psychotherapy and mental health has become common at home and abroad. Objective: We explore the effect of prescribing physical exercise in the treatment of depression in college students. Methods: College students who had been diagnosed with depression were randomly divided into an observation group and a control group, each with 18 patients. The control group received drug treatment. The observation group received sports therapy in addition to drug therapy. Results: There was a statistically significant difference in HAMD scores between the observation and control groups in the first week $(P<0.01)$. Conclusion: Exercise can play a role in treating depression patients rapidly, safely, and efficiently. Level of evidence Il; Therapeutic studies - investigation of treatment results.
\end{abstract}

Keywords: Exercises; Sports; Depressions; Treatment Protocol.

\section{RESUMO}

Introdução: A saúde mental dos estudantes universitários está recebendo cada vez mais atenção da sociedade. O exercício físico como meio de psicoterapia e saúde mental tornou-se comum no país e no exterior. Objetivo: Exploramos o efeito da prescrição de exercícios físicos no tratamento da depressão em estudantes universitários. Métodos: Estudantes universitários com diagnóstico de depressão foram divididos randomicamente em grupo observação e grupo controle, cada um com 18 participantes. O grupo controle recebeu tratamento medicamentoso. 0 grupo observação recebeu terapia esportiva acrescida de terapia medicamentosa. Resultados: Verificou-se diferença estatisticamente significativa nos escores da HAM-D entre os grupos observação e controle na primeira semana ( $P$ $<0,01)$. Conclusões: Os exercícios podem ter um papel no tratamento de pacientes com depressão de forma rápida, segura e eficiente. Nível de Evidência Il; Estudos terapêuticos - Investigação dos resultados do tratamento.

Descritores: Exercício; Esportes; Depressão; Protocolo clínico.

\section{RESUMEN}

Introducción: La salud mental de los estudiantes universitarios recibe cada vez más atención por parte de la sociedad. El ejercicio físico como medio de psicoterapia y salud mental se ha convertido en algo habitual en el país y en el extranjero. Objetivo: Explorar el efecto de la prescripción de ejercicios físicos en el tratamiento de la depresión en estudiantes universitarios. Métodos: Estudiantes universitarios con diagnóstico de depresión fueron divididos aleatoriamente en un grupo de observación y un grupo de control, los cuales contaban con 18 participantes cada uno. El grupo de control recibió tratamiento farmacológico. El grupo de observación recibió terapia deportiva y terapia farmacológica. Resultados: Se comprobó una diferencia estadísticamente significativa en las puntuaciones de HAM-D entre los grupos de observación y control en la primera semana $(P<0,01)$. Conclusiones: La actividad física puede actuar en el tratamiento de pacientes con depresión de forma rápida, segura y eficaz. Nivel de Evidencia Il; Estudios terapéuticos - Investigación de los resultados del tratamiento.

Descriptores: Ejercicio; Deportes; Depresión; Protocolo clínico.

\section{INTRODUCTION}

Depression refers to a mental illness in which a person's mood is entangled with a feeling of mental and physical discomfort and cannot be changed by self-adjustment. Its basic characteristics are low mood, lack of interest, slow thinking, slow reaction, and unwillingness to communicate with friends and colleagues. In severe cases, there are feelings of pessimism, despair, suffering, and death. Contradiction, sensitivity, and self-psychological characteristics of contemporary college students. This makes them extremely prone to various psychological disorders, of which depression is the most common. ${ }^{1}$ According to a sample survey of depression among college students, the prevalence rate of depression among college students is $23.66 \%$. This article takes college students as the research object. Follow the scientific principles and laws of fitness and study it regarding the relevant standards of depression rehabilitation. The article conducts preliminary research and exploration on the theory and practical application of rehabilitation exercise prescriptions to treat depression in college students. ${ }^{2}$ This is expected to provide a 
theoretical basis and practical experience selecting, formulating, and implementing rehabilitation exercise prescriptions for college students suffering from depression.

\section{METHOD}

\section{Research object}

The article focuses on 36 students from 4 universities who were diagnosed with depression. Among them, 11 are boys, and 25 are girls. All students have no other serious physical and mental illnesses. The article randomly divides 36 patients into two groups, A (control group) and B (observation group), and 12 people in group A maintain the existing medication and psychotherapy. Twenty-four people in group B implemented rehabilitation exercise prescriptions based on existing drugs and psychotherapy. ${ }^{3}$ The observation time for both groups was 16 weeks. We conducted follow-up observation and questionnaire measurement on all patients' depressive symptoms, physical and mental health levels, and adverse reactions before and after treatment. (Table 1)

\section{Research methods}

Formulation and implementation of rehabilitation exercise prescription

Judging the patient's condition and physical fitness is important for formulating and implementing rehabilitation exercise prescriptions. The psychologist determined the different levels of depression suffered by 36 college students. The ultimate goal (Level A): Unrestricted learning activities, normal sports and life, and close to normal physical and mental functions. B-level goal: mild depression. C-level goal: moderate depression. D-level goal: severe depression. (Table 1) Each level is divided into B1 and B2 according to the students' physical and mental status. C1, C2. Six levels of D1 and D2. After 3-4 weeks of exercise, those who reach the previous level after medical examination and psychological evaluation can be promoted, and those who have worsened depression can be degraded. ${ }^{4}$ We propose contraindications (diet, psychology, environment), self-observation indicators, and adjustment methods when abnormal indicators occur.

Theoretical teaching includes the following aspects: the basic knowledge of mental health, the nature, and pathogenesis of depression, predisposing factors, the influence of physical and mental states on depression, the influence of diet, the influence of aerobic exercise, the significance of implementing rehabilitation exercise prescriptions and their things to pay attention.

Table 1. The basic situation of $A$ and $B$ personnel.

\begin{tabular}{|c|c|c|c|}
\hline & & Group A (12) & Group B (24) \\
\hline \multirow{2}{*}{$n$} & male & 3 & 8 \\
\hline & Female & 9 & 16 \\
\hline \multirow{4}{*}{ Grade of disease severity (n) } & Class A & 0 & 0 \\
\hline & Class B & 4 & 9 \\
\hline & Class C & 6 & 12 \\
\hline & Class D & 2 & 3 \\
\hline \multirow{3}{*}{ Suicidal tendency $(n)$} & light & 5 & 7 \\
\hline & middle & 5 & 11 \\
\hline & Heavy & 2 & 6 \\
\hline \multirow{3}{*}{ Physical symptoms (n) } & light & 5 & 8 \\
\hline & middle & 5 & 10 \\
\hline & Heavy & 2 & 6 \\
\hline \multirow{3}{*}{$\begin{array}{l}\text { Communication barriers (n) } \\
\text { Grade of disease severity (n) }\end{array}$} & light & 6 & 11 \\
\hline & middle & 4 & 10 \\
\hline & Heavy & 2 & 3 \\
\hline
\end{tabular}

Practical teaching includes the following aspects. Learn how to help yourself and seek help from others when depression occurs, especially when suicidal tendencies appear. ${ }^{5}$ Master the correct physical and mental relaxation techniques: learn and master group exercises such as breathing, relaxation gymnastics, and ball games. Tai Chi exercises such as relaxation, internal nourishment, and strength.

Exercise prescription: We use different grades and levels of rehabilitation exercise prescriptions as "models." At the same time, students implement and fine-tune rehabilitation exercise prescriptions under the guidance of teachers. (Table 2)

\section{Index measurement}

Observe and test the symptoms of depression before and after the test. (Physical, suicide, communication) test indicators were measured twice to take the highest value.

\section{Data processing}

We use the data analysis tool library of the Excel software package and WJZ psychological measurement and statistics-related software for statistical processing.

\section{Gray system model analysis in the field of sports training control}

The general physical fitness module in the selection consists of multiple indicators. Each indicator requires the object to be selected to reach a certain range of values, the norm value. ${ }^{6}$ The grey relational analysis can be used to judge the closeness between the candidate's physical fitness index and the norm value to provide a reference for the scientific selection of coaches. The gray correlation analysis is used to calculate the correlation value of candidate object one and candidate object 2 concerning the norm value. Proceed as follows:

The first step: We initialize the series of numbers in Table 1. Divide itself and the other numbers $x_{i}(K)$ by the first number $x_{i}(1)$ of each series so that the dimension of the series is 1 .

Step 2: The difference sequence is the absolute difference between $x_{\mathrm{o}}(k)$ and $x_{i}(k)$ at each time. The formula is as follows:

$$
\Delta_{i}=\left|x_{0}(k)-x_{i}(k)\right|
$$

The third step: The formula for finding the maximum difference between the two poles and the minimum difference between the two poles is as follows:

The smallest difference between the two poles $\left|x_{0}(k)-x_{i}(k)\right|_{\min }$. The minimum difference of the first level is for $k$ to run through $k$ to select the minimum value. The second minimum difference is for $i$ to run through $i$ to select the minimum value. ${ }^{7}$ The maximum difference between the two poles $\left(\varepsilon_{i}(k)\right)\left|x_{\mathrm{o}}(k)-x_{i}(k)\right|_{\max }$. First run through $k$ to select the largest difference, and then run through $i$ to select the largest difference.

Table 2. Rehabilitation exercise prescriptions of different grades and levels

\begin{tabular}{c|c|c|c}
\hline & Sports & sport time & Exercise frequency \\
\hline B1 & $\begin{array}{c}\text { Fitness running, fitness } \\
\text { dancing, swimming }\end{array}$ & $45 \mathrm{~min}$ & $4-5$ times/week \\
\hline B2 & $\begin{array}{c}\text { Swimming, walking, and running } \\
\text { alternate group exercise }\end{array}$ & $50-60 \mathrm{~min}$ & 6 times/week \\
\hline C1 & $\begin{array}{c}\text { Tai Chi, swimming, walking } \\
\text { (90-100 steps/min) }\end{array}$ & $40-50 \mathrm{~min}$ & 7 times/week \\
\hline C2 & $\begin{array}{c}\text { Strengthening skills, Baduanjin, } \\
\text { walking 80-90 steps/min) }\end{array}$ & About $20 \mathrm{~min}$ & $6-7$ times/week \\
\hline D1 & $\begin{array}{c}\text { Internal exercises, breathing exercises } \\
\text { (postures are standing and sitting) }\end{array}$ & $15-20 \mathrm{~min}$ & $10-11$ times/week \\
\hline D2 & $\begin{array}{c}\text { Relaxation exercises, breathing } \\
\text { exercises (the posture is lying, lying) }\end{array}$ & About $20 \mathrm{~min}$ & $\begin{array}{c}15 \text { times/week } \\
\text { or more }\end{array}$ \\
\hline
\end{tabular}


Step 4: Calculate the correlation coefficient $\left(\varepsilon_{i}(k)\right)$, the formula:

$$
\varepsilon_{i}(k)=\frac{\left(\left|x_{0}(k)-x_{i}(k)\right|_{\min }+0.5\left|x_{0}(k)-x_{i}(k)\right|_{\max }\right.}{\left(\left|x_{0}(k)-x_{i}(k)\right|_{\max }+0.5\left|x_{0}(k)-x_{i}(k)\right|_{\max }\right.}
$$

The 0.5 in the above formula is the resolution coefficient. We mark it as $\beta$, which usually takes a value between 0 and 1 . Where $\varepsilon_{i}(k)$ is the relative difference between the comparison curve $x_{i}$ and the reference curve $x_{\mathrm{o}}$ at the $k$ time. ${ }^{8}$ The relative difference in this form is called the correlation coefficient of $x_{i}$ to $x_{0}$ at time $k$.

Step 5: Calculate the degree of relevance. The mean value of the correlation coefficient between the parent sequence and the sub-sequence is denoted as $\gamma_{i}$.

$$
\gamma_{i}=\frac{1}{N} \sum_{k=1}^{n} \varepsilon_{i}(k)
$$

As a result, the relevance value $R_{1}=0.6438$ of the candidate object 1 is obtained. The relevance value $R_{2}=0.7928$ of the object to be selected 2. This shows that the correlation between test subject 2 and the norm value of the physical fitness index is relatively large. ${ }^{9}$ Therefore, priority should be given to test subject 2 in terms of physical fitness level.

\section{RESULTS}

\section{The results of depressive symptoms}

The depression symptoms of all patients improved significantly after the test. The effective rate is calculated according to the following formula. Effective rate $=$ (controlling number + significant effective number) $\div$ total number $\times 100 \%$. In group A (control group), the effective rate of light birth improvement was $73.32 \%$, reducing physical symptoms was $59.24 \%$, and improving interpersonal communication was $52.43 \%$. The corresponding rates in group B (observation group) were $92.37 \%, 87.69 \%$, and $82.13 \%$, respectively. There was a significant difference in the effective rate of improvement of depression symptoms between the two groups A and B (see Table 3). The changes in the number of people at each level before and after the test are as follows: Group A: 1 person in Class A; 5 persons in Class B; 5 persons in Class $C ; 1$ person in Class D. Group B: 10 people in grade A; 12 people in grade $B ; 2$ people in grade $C$. (Table 4 ) The changes in the two groups of personnel were significantly different. This shows that through exercises such as breathing gymnastics, Baduanjin, Tai Chi, swimming, etc., patients' physical and mental health and the power of self-regulation have been enhanced. The patient's depression symptoms have been well improved.

\section{Improvement of physical symptoms}

There was no significant difference in the changes of the two indexes of body weight and physical health self-evaluation index before and after the test in group $A$ (control group) $(P>0.05)$. There are significant differences in sleep indicators between men and women before and after the test. This shows that drugs and psychotherapy have a certain effect on improving and improving insomnia in patients with depression ( $\mathrm{P}<0.0 .5$ ). Group B (observation group) had significant differences in body weight and health self-evaluation indexes and slept quality before and after the test $(P<0.01)$. This shows that the rehabilitation exercise prescription has a significant effect on improving and improving the physical symptoms of depression patients, especially the quality of sleep.

\section{Changes in interpersonal communication and self-perception}

There were significant differences in interpersonal communication and self-cognition changes before and after the experiment in group $B(P<0.05)$. This indicates that the depressive symptoms are gradually stable. (Table 5)

\section{Adverse reactions}

During the trial period of this study, 2 persons (18.18\%) in group A had adverse reactions, including 1 person with palpitations (9.09\%) and 1 person with insomnia (9.09\%). 4 people (20\%) in group B had mild insomnia.

Table 3. Symptoms and efficacy results.

\begin{tabular}{c|c|c|c|c|c|c}
\hline & & control & $\begin{array}{c}\text { Markedly } \\
\text { effective }\end{array}$ & Get better & Invalid & Efficient \\
\hline \multirow{2}{*}{$\begin{array}{c}\text { Commit } \\
\text { suicide }\end{array}$} & A & $5(36.36)$ & $3(27.27)$ & $3(27.276)$ & $1(9.09)$ & $9(73.32)$ \\
\cline { 2 - 7 } & B & $11(45.00)$ & $10(40.00)$ & $3(15.00)$ & 0 & $21(92.37)$ \\
\hline \multirow{2}{*}{ Body } & A & $3(27.27)$ & $2(18.18)$ & $6(45.45)$ & $1(9.09)$ & $7(59.24)$ \\
\cline { 2 - 7 } & B & $9(35.00)$ & $10(40.00)$ & $5(20.00)$ & 0 & $19(87.69)$ \\
\hline \multirow{2}{*}{ Associate } & A & $3(27.27)$ & $3(27.27)$ & $5(36.36)$ & $1(9.09)$ & $8(52.43)$ \\
\cline { 2 - 7 } & B & $12(45.00)$ & $10(35.00)$ & $2(10.00)$ & 0 & $17(82.13)$ \\
\hline
\end{tabular}

Table 4. Personnel changes at each level before and after the two groups of $A$ and B tests.

\begin{tabular}{c|c|c|c|c|c|c|c}
\hline & & \multicolumn{2}{|c|}{ N } & \multicolumn{4}{c}{ Grade of disease severity (n) } \\
\hline & & male & Female & Class A & Class B & Class C & Class D \\
\hline \multirow{2}{*}{ Group A (12) } & forward & 3 & 9 & 0 & 4 & 6 & 2 \\
\cline { 2 - 8 } & Rear & 3 & 9 & 1 & 5 & 5 & 1 \\
\hline \multirow{2}{*}{ Group B (24) } & forward & 8 & 16 & 0 & 9 & 12 & 3 \\
\cline { 2 - 8 } & Rear & 8 & 16 & 10 & 12 & 2 & 0 \\
\hline
\end{tabular}

Table 5. Changes in interpersonal communication of 24 students in group B before and after the test.

\begin{tabular}{c|c|c}
\hline & Before the test & After the test \\
\hline Interpersonal communication & $1.51 \pm 0.41$ & $1.89 \pm 0.34$ \\
\hline Self-awareness & $238.47 \pm 55.12$ & $299.54 \pm 66.28$ \\
\hline
\end{tabular}

\section{DISCUSSION}

Three weeks after the end of the study, a follow-up survey of 24 students in Group B found that 10 students were promoted to A-level. One patient had mild intermittent depression, but his symptoms resolved quickly. Twelve students were in B-level after the experiment. Two C-level students have been doing serious exercises following the requirements of the rehabilitation exercise prescription. Its physical and mental performance indicators are steadily improving. The positive results obtained in the experiment prove that the rehabilitation exercise prescription has a significant effect on improving and improving college students' physical and mental function with depression, especially the quality of sleep.

\section{CONCLUSION}

The education and management of college students with depression during treatment is an important part of implementing rehabilitation exercise prescriptions. We need to formulate rehabilitation exercise prescriptions for different groups to guide the rehabilitation exercise of patients with depression. In the promotion and popularization and when drugs can control depression, non-drug therapies such as rehabilitation exercise prescriptions should be used as much as possible to treat depression patients.

The author declare no potential conflict of interest related to this article 


\section{REFERENCES}

1. Lundqvist C. Ending an Elite Sports Career: Case Report of Behavioral Activation Applied as an Evidence-Based Intervention with a Former Olympic Athlete Developing Depression. Sport Psychol. 2020;34(4):329-36

2. Rozsnyai RA, Grosu VT, Rusu AC. The Importance of Depression, Anxiety and Stress on Sports Performance at Football Junior (14-16 Years). Gymnasium. 2021;21(2):63-81.

3. Gorham LS, Jernigan T, Hudziak J, Barch DM. Involvement in sports, hippocampal volume, and depressive symptoms in children. Biol Psychiatry Cogn Neurosci Neuroimaging. 2019;4(5):484-92.

4. Easterlin MC, Chung PJ, Leng M, Dudovitz R. Association of team sports participation with long-term mental health outcomes among individuals exposed to adverse childhood experiences. JAMA Pediatr. 2019;173(7):681-8.

5. Lichtenstein MB, Gudex C, Andersen K, Bojesen AB, Jørgensen U. Do exercisers with musculoskeletal injuries report symptoms of depression and stress?. J Sport Rehabil. 2019;28(1):46-51.

6. Junge A, Prinz B. Depression and anxiety symptoms in 17 teams of female football players including 10 German first league teams. Br J Sports Med. 2019;53(8):471-7.

7. Zuckerman SL, Tang AR, Richard KE, Grisham CJ, Kuhn AW, Bonfield CM, et al. The behavioral, psychological, and social impacts of team sports: a systematic review and meta-analysis. Phys Sportsmed. 2021;49(3):246-61.

8. Ophir Y, Lipshits-Braziler Y, Rosenberg H. New-media screen time is not (necessarily) linked to depression: Comments on Twenge, Joiner, Rogers, and Martin (2018). Clin Pscyhol Sci. 2020;8(2):374-8.

9. Branković E. Sports, mental health, and the dilemmas of fame and success: In a search of a holistic paradigm. Pannoniana: Časopis za humanističke znanosti. 2020;4(1):9-33. 